\title{
MENJADI PEMENANG SEGALA PERTANDINGAN : SEBUAH EKSPLORASI MODAL PSIKOLOGIS ATLET PEMENANG
}

\author{
Yusuf Ratu Agung, \\ M. Mirza Ayatulloh, \\ Abdul Falah Hanif T.P, \\ Fakultas Psikologi \\ Universitas Islam Negeri Maulana Malik Ibrahim Malang \\ email: ratuagung@psi.uin-malang.ac.id
}

\begin{abstract}
Abstrak. Olahraga merupakan bagian yang tidak terpisahkan dari aktifitas manusia. Menjadi pemenang dalam setiap pertandingan olahraga, merupakan tujuan dari setiap atlet yang berlaga. Tulisan ini disusun selama proses pendampingan dan pemusatan latihan atlet cabang olahraga tertentu yang tengah berkonsentrasi menghadapi even olahraga nasional. Pendampingan yang diberikan tidak hanya secara fisik, namun juga psikologis. Dari proses pendampingan psikologis inilah ditabulasikan fakta-fakta yang melatarbelakangi seorang atlet atau sebuah tim dalam memenangkan pertandingan. Tabulasi fakta yang dikumpulkan melalui observasi dan wawancara dengan analisa kualitatif-deskriptif, menghasilkan bahwa kemenangan adalah hasil dari proses kelindan antara motivasi internal, dukungan eksternal dan regulasi/strategi.
\end{abstract}

Keyword: atlet pemenang, motivasi, strategi, psikologi olahraga

PSIKOISLAMIKA. Jurnal Psikologi Islam (JPI) copyright @ 2016 Pusat Penelitan dan Layanan Psikologi. Volume 13 Nomor 2 Tahun 2016

\section{PENDAHULUAN}

Terdapat beberapa pertanyaan klasik ketika psikologi turut mengambil peran dalam bidang olahraga, yakni apakah ada profil psikologis khusus dari atlet yang sukses, bagaimana karakterkarakter atlet pemenang ataupun apakah atlet perlu membangun kepribadian khusus agar bisa selalu menjadi pemenang (Kremer \& Scully, 1994, p.14). Selanjutnya muncul pertanyaan menarik, siapakah yang dianggap sebagai atlet pemenang? Jawaban yang muncul adalah mereka yang mencapai puncak prestasi dalam olahraga yang digelutinya (Teitelbaum, 2005, p.18). Lebih lanjut Teitelbaum (2005) menjelaskan atlet pemenang segera akan menjelma menjadi pahlawan tidak hanya bagi keluarganya namun juga pahlawan bagi semua orang yang menyukai olahraga.

Olahraga sebagai salah satu aktifitas popular manusia telah menjadi kegandrungan sepanjang sejarah manusia. Pertandingan-pertandingan olahraga senantiasa dipenuhi oleh penggemarnya. Menilik dari sejarah, aktifitas berolahraga merupakan upaya pemenuhan kebutuhan sekaligus kebutuhan manusia itu sendiri. Mulai dari inspirasi aktivitas pemenuhan kebutuhan bertahan hidup dengan cara berburu hingga tradisi perhelatan olahraga sebagai persembahan kepada dewa di Olympus yang masih dilangsungkan sampai kini (Swaddling, 2000). Olahraga saat ini telah menjadi kebanggaan sekaligus prestasi secara personal, bahkan juga menjelma sebagai national pride.

Dalam setiap pertandingan olahraga, meniscayakan munculnya seorang pemenang. Dalam perspektif psikologi, pemenang yang sesungguhnya bukan hanya memenangkan pertandingan dengan mencatatkan diri sebagai seorang yang terkuat, tercepat, tertinggi, terjauh maupun terindah dibandingkan atlet pesaingnya, melainkan peningkatan harga diri atas pencapaian optimal dari performanya. Terlebih bagi para atlet yang mengikuti nomor-nomor perlombaan 
tingkat nasional dan internasional,kemenangan menjadi tidak sekedar bernilai personal pride, namun juga national pride.

Lantas, bagaimana para atlet tersebut mampu mencapai kemenangan?. Strategi menjadi kunci jawabannya. Strategi merupakan suatu rencana yang disusun untuk mencapai sebuah tujuan yang diinginkan. Rencana-rencana yang dimaksudkan meliputi tujuan, kebijakan, dan tindakan yang harus dilakukan untuk mempertahankan eksistensi dan memenangkan persaingan. Dibutuhkan lebih dari sebuah strategi untuk mempersiapkan kondisi atlet agar prima dalam pertandingan. Mulai strategi latihan, fisik maupun mental, serta strategi ketika berada dalam pertandingan. Hal ini menjadi menarik, karena terdapat keragaman pendapat para atlet dalam menyusun strategi.

Atlet yang mampu membuat strategi mereka sendiri memiliki dorongan yang kuat. Dorongan tersebut dalam konteks psikologi dikenal dengan motivasi. Motivasi dapat dibangun dalam berbagai kondisi dan situasi. Kondisi menyenangkan maupun mendesak, dan juga situasi aman maupun tidak aman.

Tanpa adanya motivasi yang kuat, seorang atlet sulit berhasil dalam pertandingan. Meskipun atlet tersebut mempunyai keterampilan yang baik, tetapi tidak ada motivasi untuk bermain baik, maka akan mengalami kekalahan. Hasil yang optimal hanya dapat dicapai kalau motivasi dan keterampilan saling melengkapi. Seperti yang dinyatakan Aldeman (dalam Gunarsa, 1989) bahwa dalam bidang pendidikan jasmani dan olahraga, tidak ada atlet yang dapat menang tanpa motivasi.

Terdapat beberapa ciri-ciri khusus individu yang bermotivasi tinggi yaitu: mengambil tingkat aspirasi sedang, lebih memilih resiko yang sedang dari pada yang tinggi, berjuang untuk prestasi sosial, perspektif waktunya berorientasi ke depan, ada dorongan untuk menyelesaikan tugas yang belum selesai, ulet dalam mengerjakan tugas dengan kesukaran tertentu, memilih rekan tim atas dasar kemampuan, dan usahanya sangat menonjol (Amini, 1997).

Motivasi olahraga adalah keseluruhan daya penggerak (motif-motif) di dalam diri individu yang menimbulkan kegiatan berolahraga, menjamin kelangsungan latihan dan memberi arah pada kegiatan latihan untuk mencapai tujuan yang dikehendaki (Gunarsa, 1987). Motivasi olahraga dapat dibagi atas motivasi primer dan sekunder; dapat pula atas motivasi biologis dan sosial. Namun banyak ahli setuju membagikannya atas dua jenis, yaitu intrinsik dan ekstrinsik. Motivasi intrinsik adalah dorongan dari dalam yang menyebabkan individu berpartisipasi. Atlet yang mempunyai motivasi intrinsik akan mengikuti latihan peningkatan kemampuan atau ketrampilan, atau mengikuti pertandingan, bukan karena situasi buatan (dorongan dari luar), melainkan karena kepuasan dalam dirinya. Bagi atlet tersebut, kepuasan dalam dirinya diperoleh lewat prestasi yang tinggi bukan lewat pemberian hadiah, pujian atau penghargaan lainnya. Atlet ini tekun, bekerja keras, teratur, dan disiplin dalam menjalani latihan serta tidak menggantungkan diri pada orang lain. Pada umumnya atlet ini mempunyai kepribadian yang matang, jujur, sportif, tekun, percaya diri, disiplin, dan kreatif. Aktivitas yang dilandasi oleh motivasi intrinsik bertahan lebih lama dibandingkan dengan motivasi lainnya.

Selain motivasi yang dibutuhan kemudian adalah strategi psikologis. Menurut Marrus (2002) strategi didefinisikan sebagai suatu proses penentuan rencana para pemimpin puncak yang berfokus pada tujuan jangka panjang organisasi, disertai penyusunan suatu cara atau upaya bagaimana agar tujuan tersebut dapat dicapai. Selanjutnya Quinn (1999) mengartikan strategi adalah suatu bentuk atau rencana yang mengintegrasikan tujuan-tujuan utama, kebijakan-kebijakan dan rangkaian tindakan dalam suatu organisasi menjadi suatu kesatuan yang utuh. Strategi diformulasikan dengan baik akan membantu penyusunan dan pengalokasian sumber daya yang dimiliki perusahaan menjadi suatu bentuk yang unik dan dapat bertahan. Strategi yang baik disusun berdasarkan kemampuan internal dan kelemahan perusahaan, antisipasi perubahan dalam lingkungan, serta kesatuan pergerakan yang dilakukan oleh mata-mata musuh. Dari kedua pendapat diatas, maka strategi dapat diartikan sebagai suatu rencana yang disusun oleh manajemen puncak untuk mencapai tujuan yang diinginkan. Rencana ini meliputi : tujuan, kebijakan, dan tindakan yang harus dilakukan oleh suatu organisasi dalam mempertahankan eksistensi dan menenangkan persaingan.

Sementara itu menurut Argyris, Mintzberg, Steiner, dan Miner seperti yang dikutip dalam Rangkuti (1998) menyatakan bahwa strategi merupakan respon secara terus menerus maupun adaptif terhadap peluang dan ancaman eksternal serta kekuatan dan kelemahan internal yang dapat mempengaruhi organisasi. Bryson (2001) menjelaskan bahwa strategi dapat dipandang sebagai pola tujuan, kebijakan, 
progam tindakan, keputusan atau alokasi sumber daya yang mendefinisikan bagaimana organisasi itu, apa yang dilakukan dan mengapa organisasi melakukannya.

Goldworthy dan Ashley (1996) mengusulkan tujuh aturan dasar dalam merumuskan suatu strategi sebagai berikut : a).la harus menjelaskan dan menginterpretasikan masa depan, tidak hanya masa sekarang b).Arahan strategi harus bisa menentukan rencana dan bukan sebaliknya $c)$. Strategi harus berfokus pada keunggulan kompetitif, tidak semata-mata pada pertimbangan keuangan d). la harus diaplikasikan dari atas ke bawah, bukan dari bawah ke atas e).Strategi harus mempunyai orientasi eksternal f).Fleksibilitas adalah sangat esensial g).Strategi harus berpusat pada hasil jangka panjang. Dari berbagai pendapat diatas, dapat disimpulkan bahwa penyusunan strategi harus memperhatikan tujuan dan sasaran yang akan dicapai di waktu yang akan datang, selain itu suatu organisasi harus senantiasa berinteraksi dengan lingkungan dimana strategi tersebut akan dilaksanakan, sehingga strategi tersebut tidak bertentangan melainkan searah dan sesuai dengan kondisi lingkungan dan melihat kemampuan internal dan eksternal yang meliputi kekuatan dan kelemahan.

Atlet yang telah mencapai prestasi, akan memiliki motivasi yang besar karena telah merasakan keberhasilan atau keinginan untuk mempertahankannya. Sedangkan atlet-atlet yang belum sepenuhnya optimal dalam prestasi, akan berusaha sekuat tenaga untuk mendapatkan itu semua. Tulisan ini membahas tentang bagaimanakah strategi yang dimiliki oleh atlet, urgensi aspek psikologis, serta motivasi apa saja yang melatarbelakangi kemenangan dalam sebuah pertandingan. Tulisan ini disusun pada saat pendampingan dan persiapan sebuah tim cabang olahraga yang mendalami pelatihan intensif kota Malang, Jawa Timur dalam mengahadapi PON 2016.

\section{METODE}

Tulisan disusun melalui pendekatan kualitatif yang lebih menekankan pada penggalian makna dalam melihat sebuah perilaku atau suatu aktivitas. Menurut Bagman dan Taylor (dalam Sudarto, 1995) mendefinisikan metodologi kualitatif sebagai prosedur ilmiah yang menghasilkan data deskripsi berupa kata-kata tertulis atau lisan dari orangorang dan perilaku yang diamati. Sedangkan Kirk dan Miller (dalam Suprayogo dan Tobroni, 2001) mendefinisikan bahwa metode kualitatif adalah tradisi tertentu dalam ilmu pengetahuan sosial yang secara fundamental bergantung pada pengamatan pada manusia dalam kawasannya sendiri dan berhubungan dengan orang-orang tersebut dalam bahasannya dan peristilahannya .Secara umum penelitian kualitatif bertujuan untuk memahami (understanding) dunia makna yang disimbolkan dalam perilaku masyarakat menurut perspektif masyarakat itu sendiri.

Tulisan ini berusaha untuk mendeskripsikan, mencatat, analisis dan menginterpretasikan kondisi yang sekarang ini terjadi atau ada. Dengan kata lain penelitian ini merupakan deskriptif kualitatif yang bertujuan untuk memperoleh informasi-informasi mengenai keadaan yang ada (Mardalis, 1999), dan dirancang untuk mengumpulkan informasi tentang keadaan-keadaan nyata sekarang yang sementara berlangsung ( Cevilla, 1993, p.71). Pada hakikatnya penelitian deskriptif kualitatif adalah suatu metode dalam meneliti status sekelompok manusia, suatu objek dengan tujuan membuat deskriptif, gambaran atau lukisan secara sistematis, faktual dan akurat mengenai fakta-fakta atau fenomena yang diselidiki (Cevilla, 1993).

Tulisan ini didasarkan atas temuan pada penelitian yang dilaksanakan di sebuah Training Center Atlet yang berada di Malang, Jawa Timur. Alasan dipilihnya atlet cabang olahraga ini disebabkan cabang olahraga ini menjadi sorotan dalam setiap penyelenggaraan PON maupun ASEAN Games yang dilaksanakan secara rutin. Nomor-nomor yang dilombakan cabor terpilih ini juga merupakan nomor lomba yang ditargetkan mendapatkan medali emas.

Sumber data primer dalam penelitian ini merupakan data yang diperoleh dari informan yaitu orang yang berpengaruh dalam proses perolehan data atau bisa disebut key member yang memegang kunci sumber data penelitian ini, karena informan benar-benar tahu dan terlibat dalam kegiatan yang ada di Training Center tersebut, yaitu 2 orang Pelatih senior dan 3 orang atlet. Penetapan informan ini dilakukan dengan mengambil orang yang telah terpilih menurut ciri-ciri spesifik yang dimiliki oleh sampel atau memilih sampel yang sesuai dengan tujuan penelitian.

Metode pengumpulan data yang digunakan peneliti adalah wawancara bersama antara lain pelatih atlet dan atlet. Hal demikian dilakukan dengan tujuan untuk memperoleh data secara luas dan menyeluruh sesuai dengan kondisi saat ini. Selain wawancara, observasi langsung dilakukan oleh peneliti bisa direalisasikan dengan cara mencatat 
berupa informasi yang berhubungan dengan latihan fisik yang dijalani oleh atlet dan motivasi yang diberikan oleh pelatih langsung kepada atlet. Dengan observasi secara langsung, peneliti dapat memahami konteks data dalam berbagai situasi, sehingga dapat memperoleh pandangan secara menyeluruh.

\section{HASIL}

Pada dasarnya, seorang atlet dinilai menurut apa yang telah dicapai selama kiprahnya menjadi seorang atlet dan durasi lama atlet tersebut berkutat dalam bidang atlet tersebut. Dalam perspektif olahraga maupun psikologi, kemampuan individu bersifat dinamis, naik dan turun, bertambah dan berkurang. Namun kemampuan seorang atlet juga dapat berkembang dengan sangat luas.

Para atlet yang mampu mengembangkan potensi mereka hingga batas terakhir diri mereka akan menjadi idola atas apa yang telah diraihnya. Tetapi atlet yang profesional dan senior masih berkesempatan melakukan pertandingan dengan mengecewakan karena dinamika kemampuan yang secara alami berfluktuasi. Bagaimanakah seorang atlet yang sangat berpengalaman dapat jatuh dalam pertandingan yang seharusnya dapat ia menangkan dengan mudah.

Berdasarkan temuan peneliti, seorang atlet dibentuk dari tiga hal mendasar dan utama untuk dapat menjadi seorang pemenang, yaitu:

a. Motivasi dasar, daya saing dan kepercayaan diri

Motivasi dasar adalah tekad awal yang dimiliki saat pertama kali memutuskan untuk bergabung dalam dayung dan bergelut dalam bidang tersebut. Keteguhan hati untuk tetap menjadi atlet dan tidak pernah mundur adalah penting untuk menghadapi lawan. Entah melawan diri sendiri atau orang lain.

Semakin profesional seorang atlet, maka semakin banyak pula kompetisi dan kejuaraan yang akan dihadapi, yang tentu saja hal ini juga berhubungan dengan goal orientations milik atlet tersebut. Apabila tujuan tersebut telah dimiliki, maka atlet tidak akan berpaling pada hal lain, dalam hal ini, menurut pelatih, goal orientations yang dimiliki atlet adalah kemenangan dan title juara (S1.8/4), bukan uang, gaji atau hal-hal lain karena hanya akan menghambat fokus atlet (S2. 9/7).

Goal orientations tidak dipandang sebagai ancaman atau kebutuhan dasar. Lebih dari itu, hal tersebut dipandang sebagai sebuah skema kognitif dalam diri atlet yang dinamis dan berubah seiring bertambahnya informasi dan pengalaman. Nicholls (1989) mengungkapkan bahwa untuk mengetahui goal orientations seseorang, individu tersebut harus ditanya tentang situasi apa atau keadaan apa yang membuat mereka merasa sukses dan telah melakukan yang terbaik. Bukan membahas tentang pandangan pribadi mereka tentang apa yang sekedar mereka lakukan atas suatu kondisi.

Nicholls (1989) menambahkan, bahwa bagaimana seseorang akan percaya bahwa dirinya akan mampu mencapai apa yang ia anginkan lewat jalan membuat uraian tentang bagaimana langkah-langkah untuk mencapai semua itu. Hal ini berlaku bagi atlet yang merasa memiliki bakat rendah atau bahkan tidak memiliki bakat sama sekali. Menanamkan pengertian dalam pikiran mereka tentang potensi atau bakat yang menyebabkan seseorang sukses hanya akan membebani mereka. Atlet tersebut akan merasa semakin frustasi dan rendah diri karena berpendapat bahwa jika dari awal ia tidak berbakat, ia selamanya tidak akan mampu sukses sebagai seorang atlet.

Sedangkan dari sisi atlet, pertandingan yang dijalani harus dengan dasar keikhlasan. Karena tanpa itu, kita hanya akan fokus pada yang lain, bukan pada tujuan utama kita (S1.8/4). Jalan yang terbaik adalah menanamkan pengertian bahwa sebenarnya kesuksesan itu dapat diraih tanpa mengandalkan bakat. Orang berbakat pun dapat dikalahkan dengan kerja keras dan latihan. Secara psikis, para atlet itu akan merasa ada jalan yang terbuka bagi mereka untuk mendapatkan posisi puncak. Bakat itu sebenarnya nomor kesekian, karena bakat itu bisa dikalahkan dengan kemauan untuk terus berlatih dan disiplin. Jika disiplin dan fokus target telah terkonsep dalam diri, maka target itu akan dapat dicapai. Itulah saat kita dapat menjadi yang terbaik (S2.9/7).

b. Lingkungan Belajar

Setelah atlet mampu berkembang berdasarkan motivasi utama diri mereka, fase selanjutnya adalah membentuk lingkungan yang mampu membantu mereka berkembang. Lingkungan yang dimaksud dapat berupa rekan sesama atlet, pelatih, sarana, dan juga tempat tinggal. Semua hal tersebut harus mendukung dan 
mencukupi kebutuhan atlet selama kebutuhan latihan.

Sebagaimana yang sudah diketahui, belajar adalah suatu proses yang berubah seiring dengan perilaku seseorang sebagai hasil dari berbagai pengalaman. Para psikolog kognitif telah menyatakan bahwa belajar akan menghasilkan informasi yang utuh dan membentuk sebuah rangkaian memori dalam otak manusia. Namun memori tersebut juga akan berubah sesuai dengan masanya. Seiring bertambahnya informasi dan pengalaman, maka memori tersebut akan diperbaharui secara otomatis.

Schmidt's (1975) mengatakan bahwa skema pemikiran yang didukung oleh pengalaman lebih memudahkan pembelajaran apabila dibandingkan dengan pembelajaran yang hanya dilakukan dengan menyelesaikan tugas. Bagi atlet, dalam setiap pertandingan ataupun latihan adalah pengalaman yang berharga dan harus diikuti dengan evaluasi oleh pelatih.

$\mathrm{Hal}$ ini berhubungan dengan gaya belajar para alet yang selalu berhubungan dengan pengalaman mereka. Para pelatih juga adalah mantan atlet yang tahu cara terbaik mengolah fisik agar dapat sesuai dengan yang dibutuhkan (S1.8/4). Semuanya tidak bisa lepas dari bagaimana kita menyikapi pengalaman kita. Seperti halnya setiap latihan yang kita jalani, kita evaluasi apa saja perkembangan kita dan target apa saja yang belum kita capai ( $\$ 2.9 / 7)$

Tidak boleh ada istilah membuang-buang waktu atau membuang tenaga untuk melatih hal-hal yang tidak menjadi poin itni seorang atlet. Para atlet tentu saja harus fokus dalam membentuk kemampuan apa yang dapat membantu atlet untuk menjadi yang terbaik. Kemampuan seperti kecepatan, keseimbangan, kelenturan, kecepatan respond an sebagainya. Fokus latihan harus ditargetkan untuk mengembangkan kemampuan-kemampuan tersebut. Karena apabila tidak fokus, maka atlet akan kehabisan tenaga dan waktu.

Latihan yang terlalu umum hanya akan membawa kemampuan yang umum pula. Para pelatih telah menyesuaikan model latihan dan materi latihan sesuai dengan kemampuan apa yang ingin dibentuk dalam diri atlet.

c. Pola gerakan dan kinerja motorik

Pertumbuhan secara istilah mengacu pada perkembangan ukuran pribadi dan individual dalam skala besar dan panjang. Bukan pada tingkat kematangan seperti dalam kajian psikologis. Bagi atlet, yang sejak muda telah dididik dengan tekanan besar utnuk menghasilkan kekuatan fisik dan kemampuan yang mumpuni seringkali dikhawatirkan tidak mampu untuk tumbuh secara optimal.

Skala pertumbuhan fisik dapat dirubah seiring dengan perubahan massa otot, sedangkan kematangan setiap atlet hanya dapat dinilai dari bagaimana bentuk-bentuk perilaku atlet tersebut dalam kesehariannya. Pada umumnya kematangan psikologis tidak otomatis tumbuh bersama tubuh dan kekuatan fisik. Massa otot remaja dapat menyamai atau bahkan melebihi massa otot orang dewasa, tetapi kematangan yang dimiliki tetap berbeda. Hal ini akan berdampak besar pada pengambilan keputusan dan penyelesaian masalah.

Faktor penting dalam pertumbuhan dan pengembangan kemahiran skill motorik dalam olahraga tidak bersifat absolut tetapi bersifat relatif. Pertumbuhan yang relatif mengacu pada fakta bahwa banyak bagian tubuh yang akan berubah secara keseluruhan saat mencapai usia tertentu. Efek latihan fisik dasar seperti melempar, lari, menangkap, akan sangat terasa fungsinya ketika menghadapi latihan yang sebenarnya. Saat usia muda yang telah terbiasa dengan latihan motorik beban tinggi maka seiring bertambahnya usia akan menimbulkan kekuatan fisik yang luar biasa. Kemampuan motorik yang mumpuni merupakan hal fundamental bagi atlet untuk dapat menjalankan pekerjaan mereka.

Latihan fisik berat penting untuk mempersiapkan diri kita pada segala situasi, kita tidak akan bisa ada pada performa terbaik kita ketika kita bermalas-malasan tanpa berlatih (\$1.8/4). Latihan-latihan fisik ala kemiliteran menjadi kunci dalam membangun kecepatan, kelenturan tubuh, kecepatan, dan respon cepat. Itulah fungsi kita sebagai atlet diberi latihan gabungan bersama dengan para tentara (S2.9/7). Tanpa diragukan lagi, latihan sudah sejak dulu ditetapkan sebagai dasar dari olahraga. Tanpa latihan dasar dan disiplin, para atlet yang telah direkrut sejak muda hanya akan tumbuh tanpa berkembang sesuai dengan target yang diinginkan.

Secara sederhana temuan tersebut dapat digambarkan dalam diagram berikut : 


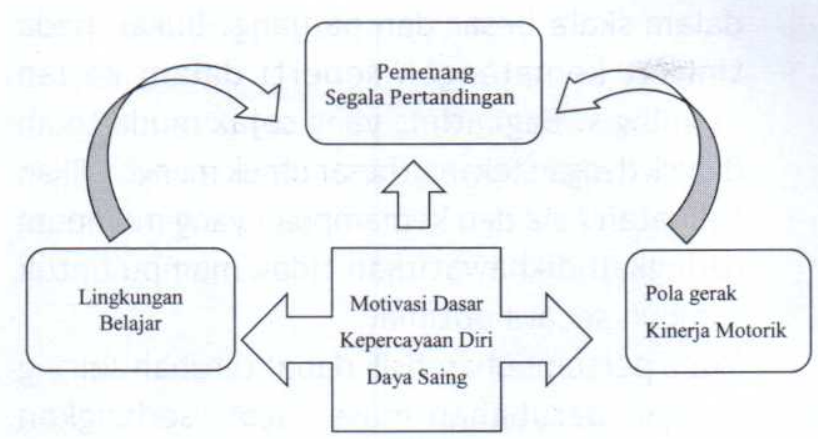

Gambar 1: Diagram alir temuan penelitian

\section{DISKUSI}

Tulisan ini menunjukkan bahwa kinerja optimal dari atlet akan tercapai bila melibatkan proses terbangunnya motivasi internal (dasar) yang baik dengan meletakkan kesadaran akan daya saing dari dalam diri atlet. Daya saing inilah yang akan memunculkan kekuatan untuk mendobrak batasan kognitif dari atlet. Hal ini hanya bisa muncul apabila kepercayaan diri dari atlet terbangun dengan baik pula. Mekanisme membangun dari motivasi dasar inilah yang akan menjadi pekerjaan panjang pendamping psikologis dari atlet. Karena kebutuhan tiap atlet dan bahkan tiap tim akan sangat berbeda. Kesadaran ini memerlukan kemampuan dari individu atlet untuk melakukan self assessment sebagai representasi dari pengetahuan diri. Corlett (1996) menuturkan, pengetahuan diri yang baik dapat menumbuhkan motivasi dasar yang baik dan kuat untuk menjadi pemenang dalam pertandingan. Riset berikutnya dapat dikembangkan pada penemuan pola generic dari pembangunan motivasi dasar yang kompatibel dengan orientasi atlet.

Keberadaaan motivasi eksternal, seperti lingkungan belajar yang mendukung telah menjadi

\section{DAFTAR PUSTAKA}

Amini, M., (1997).,Studi teoretik hubungan kecemasan dengan motivasi berprestasi anak usia 7-12 tahun. Tesis (Tidak Diterbitkan). Fakultas IImu Pendidikan IKIP, Jakata

Bandura, A., (1982), 'Self-Efficacy Mechanism In Human Agency', American Psychologist, 37, Pp. 122-47.

Brehm, Sharon, \& Kassin, Saul, (1996), Social Psychology. Third Edition. New Jersey: Houghton Mifflin Company.

Bryson, John, (2001), Perencanaan Strategis Bagi Organisasi Sosial. Yogyakarta: Pustaka pelajar. perhatian para behavioris, tidak hanya di dunia pendidikan namun juga dunia terapan lainnya, seperti olahraga. Bila dikolaborasikan dengan strategi, maka dukungan eksternal akan memunculkan pengkondisian dan pembiasaaan yang dapat dijadikan pendorong bagai motivasi dasar atlet untuk mencapai performa optimalnya.

Sebuah asumsi yang lebih jauh dapat diverifikasikan adalah relasi antara kerpercayaan diri dengan daya saing, utamanya dalam setting psikologi olahraga, karena banyak diantara atlet merasa dirinya mampu namun mendapati dirinya tidak masuk line up utama dalam pertandingan. Hal ini kadang memunculkan protes atlet pada pelatih atau manager. Riset verifikasi relasi ini bisa dijadikan modal untuk melakukan peningkatan kesadaran diri atlet dalam memberikan prestasi dan performa terbaiknya.

\section{KESIMPULAN}

Tulisan ini sebagai bagian dari proses pendampingan tentunya memiliki keterbatasan, yaitu keunikan subjek dan setting penelitian. Hal yang menarik adalah munculnya daya saing sebagai kesadaran akan pengetahuan diri atlet. Kesadaran akan daya saing ini bisa berakibat pada munculnya underestimatting kompetitor yang tentunya malah akan berdampak tidak baik pada performa atlet.

Tulisan ini menyimpulkan bahwa kemenangan merupakan hasil dari proses kelindan antara motivasi internal, dukungan eksternal dan regulasi/strategi. Ketiga aspek tersebut memberikan kontribusi atas peningkatan prestasi atlet, khususnya merupakan faktor utama bagi seorang atlet untuk mencapai performa optimalnya.

Burhan Bungin, (2004), Metodologi Penelitian Sosial: Format-format Kualitatif dan Kuantitatif, 124

Cevilla, Convelo G, (1993), Pengantar Metode Penelitian, Jakarta: Universitas Indonesia, p, 73

Corlett, J., (1996), 'Sophistry, Socrates and sport psychology', The Sport Psychologist, 10:84-94.

Dimyati, Herwin, TriAni Hastuti., (2013), Karakteristik Psikologis Atlet di Pusat Pendidikan dan Latihan Pelajar (PPLP). Jurnal Psikologi Vol. 40 No. 2 Desember 2013. P. 143-158 
Fitts, P. And Posner, M.I., (1967), Human Performance, Belmont, CA: Brooks-Cole.

Gill, D. L., dan Deeter, T. E., (1988), Development Of The Sport Orientation Questionnaire. Research Quarterly For Exercise And Sport, 59, 191-202.

Gill, D.L., (1986), Psychological Dynamics of Sport, Champaign, IL: Human Kinetics. Goldworthy

Gunarsa, Singgih D., (1989) Psikologi Olahraga. Jakarta : PT. BPK Gunung Mulia.

Hadi, Rubianto, (2011), Peran Pelatih dalam Membentuk Karakter Atlet. Jurnal Media IImu Keolahragaan Indonesia. Vol 1. Edisi 1. Juli 2011. P. 88-93

Harter, S., (1982), 'Effectance Motivation Reconsidered: Towards A Developmental Model', Human Development, 21, Pp. 34-64.

Suprayogo, Imam dan Tobroni, (2001), Metode Penelitian Sosial Agama cet. 1, Bandung : Remaja Rosdakarya.

Jensen, R.K., (1981), 'The Effect Of A 12-Month Growth Period On The Body Moments Of Inertia Of Children', Medicine And Science In Sports And Exercise, 13, Pp. 238-42.

Kremer, John and Scully, Deirdre, (1994), Psychology in Sport, Philadelphia : USA Psychology Press Ltd.

Keogh, J. And Sugden, D., (1985), Movement Skill Development, New York: Macmillan.

Mardalis, (1996), Metode Penelitian Suatu Pendekatan Proposal, Jakarta : Bumi Aksara, p, 26

Marrus, (2002), Manajemen Pelayanan Umum di Indonesia. Jakarta: PT. Bumi Aksara

Moleong, Lexy J., (2013), Metode Penelitian Kualitatif Bandung: Remaja Rosdakarya 178

Muskanan, Kaarel., (2015), Analisis Motivasi Berprestasi Altlet Pusat Pendidikan dan Latihan Olahraga Pelajar (PPLP) Provinsi Nusa Tenggara Timur. Jurnal Kebijakan \& Administrasi Publik Vol. 19 No. 2 November 2015 p. $105-113$

Nasution, S., (1996), Metode Research, Jakarta : Bumi Aksara. p, 99

Quinn, James Brian, Hennry Mintzberg, \& Robbert M.James., (1999), The Strategy Process : Concepts, Contexts and Cases Prentice Hall. Inc New Jersey
Rangkuti, Freddy., (1998), Analisis SWOT Teknik Membedah Kasus Bisnis. Jakarta: Gramedia Pustaka Utama, 1998), 4.

Roberton, M.A., (1982), 'Describing “Stages” Within And Across Motor Tasks', In KELSO, J.A.S. And CLARK, J.E. (Eds) The Development of Movement Control And Coordination, New York: John Wiley And Sons, Pp. 293-307.

Sardiman A.M., (2009), Interaksi dan motivasi belajar mengajar. Jakarta: Radjagrafindo Persada

Shephard, R.J., (1982), Physical Activity And Growth, Chicago, IL: Year Book Medical Publishers.

Singarimbun, Masri, dan Efendi Sofwan., (1989), Metode Penelitian Survei, Jakarta : LP3S.

Soeratno. (1995). Metodologi Penelitian, Yogyakarta : UUP AMP YKPN, p. 99

Spence, J.T., And Helmreich, R.L., (1978), Masculinity And Femininity, Austin, TX: University Of Texas Press.

Sudarto, (1995), Metodologi Penelitian Filsafat, (Jakarta : Raja Grafindo Persada, 1995), 63-64

Swaddling, Judith (2000), The Ancient Olympic Games (2 ed.). Austin: University of Texas Press. p. 54. ISBN 0-292-70373-2. OCLC 10759486. Diakses tanggal 6 June 2009.

Teitelbaum, Stanley H., (2005), Sports heroes, fallen idols, Lincoln and London : University Of Nebraska Press.

Tenenbaum, Gershon., And Eklund, Robert C,. (2007), Handbook of Sport Psychology: Third Edition. John Wiley \& Sons, Inc. Hoboken, New Jersey

Thomas, J.R., French, K.E., Thomas, K.T., And Gallagher, J.D., (1988), ‘Children's Knowledge Development And Sport Performance', In SMOLL, F., MAGILL, R. And ASH, M. (Eds) Children And Sport, 3rd Edn, Champaign, IL: Human Kinetics, Pp. 179-202.

Vallerand, R.J., Deci, E. L And Ryan, R.M. (1987) 'Intrinsic Motivation In Sport', In Pandolf, K.B. (Ed.) Exercise And Sport Sciences Reviews, Vol. 15, New York: Macmillan, Pp. 48-57.

Vealey, R.S., (1986), 'Conceptualization Of Sport Confidence And Competitive Orientation: Preliminary Investigation And Instrument Development', Journal Of Sport Psychology, 8, Pp. 221-46. 
Weiss, M.R., And Chaumeton, N., (1992) 'Motivational Orientations In Sport', In HORN, T.S. (Ed.) Advances In Sport Psychology, Champaign, IL: Human Kinetics, Pp. 61-100. 